\title{
ГОТОВНІСТЬ МАЙБУТНІХ УЧИТЕЛІВ МУЗИКИ ДО СПІВПРАЦІ 3 УЧНЯМИ В ОСВІТНЬОМУ ПРОЦЕСІ НОВОЇ УКРАЇНСЬКОЇ ШКОЛИ
}

\author{
Валентина Замороцька \\ кандидат педагогічних наук, \\ доцент кафедри музики і хореографії \\ ДВНЗ «Донбаський державний педагогічний університет» \\ м. Слов'янськ, Україна \\ zamorotska@i.ua
}

\section{Володимир Смиренський}

кандидат педагогічних наук, доцент, викладач-спеціаліст циклової комісії «Хорове диригування»

КЗ «Бахмутський фаховий коледж культури і мистецтв ім. І. Карабиця» м. Бахмут, Україна

ORCID ID 0000-0002-0837-0167

smirensk22@gmail.com

\begin{abstract}
Анотація. У статті висвітлено окремі аспекти формування професійної компетентності майбутнього вчителя музики, зокрема актуальну в контексті реформування загальної середньої освіти проблему готовності педагога до співпраці з учнями в освітньому процесі Нової української школи. Автори визначають формування готовності майбутніх учителів музики до співпраці з учнями як процес і результат виховання загальнолюдських та професійних цінностей студентів, професійно важливих якостей, засвоєння ними знань та оволодіння вміннями, що забезпечують ефективність міжособистісного та мистецького діалогу, реалізацію музичної співтворчості з учнями в освітньому процесі. У структурі поняття авторами виокремлено і схарактеризовано особистісно-аксіологічний, когнітивний та праксеологічний компоненти.
\end{abstract}

Ключові слова: професійна підготовка; майбутні вчителі музики; готовність до співпраці; структура.

Постановка проблеми в загальному вигляді. Реформування вітчизняної системи вищої освіти відповідно до вимог Болонської декларації передбачає розроблення нових галузевих стандартів на засадах компетентнісного підходу, що забезпечить підготовку конкурентоспроможних фахівців, здатних швидко адаптуватися в нових умовах і на високому рівні здійснювати професійну діяльність. Концепція «Нова українська школа» (2016) одним із провідних принципів організації освітнього процесу в школах визначає педагогіку партнерства, що зумовлює посилення уваги до підготовки майбутніх учителів музики до співпраці з учнями на уроках. В основі педагогіки партнерства демократичний спосіб співпраці між учителем, учнем і батьками, які об'єднані 
спільними цілями та прагненнями, $€$ добровільними й зацікавленими спільниками, рівноправними учасниками освітнього процесу, відповідальними за результат. Учитель має бути другом, а родина - залучена до побудови освітньої траєкторії дитини. Педагогіка партнерства передбачає безумовну рівність у праві на повагу, довіру, доброзичливе ставлення i взаємну вимогливість.

Сутність педагогіки партнерства полягає в демократичному та гуманному ставленні до дитини, забезпеченні їй права на вибір, на власну гідність, на повагу, права бути такою, якою вона $\epsilon$, а не такою, якою хоче ії бачити вчитель.

Стосунки партнерства складаються там, де діти й дорослі об'єднані спільними поглядами та прагненнями. Педагогіка партнерства бачить в учневі добровільного і зацікавленого соратника, однодумця, рівноправного учасника педагогічного процесу, турботливого і відповідального за його результати.

Аналіз останніх досліджень і публікацій. Аналіз наукової літератури показав, що виявлення особливостей підготовки майбутніх учителів музики до співпраці з учнями має здійснюватися 3 урахуванням специфіки музичнопедагогічної освіти в закладах вищої освіти, що характеризується такими теоретичними положеннями: про цінності співпраці в музично-педагогічній діяльності (Д. Кабалевський, В. Дряпіка, О. Олексюк, Г. Падалка, Т. Смирнова); про підготовку майбутніх учителів у системі мистецької освіти (Л. Масол, О. Отич, О. Рудницька); особливості музично-педагогічної діяльності майбутнього вчителя музики (Л. Беземчук, О. Рудницька, Т. Ткаченко); про мистецький діалог (М. Бахтін, М. Каган, О. Олексюк, О. Рудницька, М. Ткач) та музичну співтворчість (І. Козирева, Н. Мозгальова, В. Цалієв). Докладніше розглянемо особливості музично-педагогічної освіти в контексті підготовки майбутніх учителів музики до співпраці з учнями в умовах Нової української школи.

Більшість авторів досліджують окремі аспекти підготовки майбутніх учителів музики до співпраці з учнями. О. Рудницька розглядала окремі питання підготовки майбутніх учителів музики до співпраці 3 учнями. Зокрема, акцентовано увагу на ролі «стилю співпраці», який необхідно вдосконалювати в процесі художнього спілкування вчителя та учнів. Цей стиль, на думку автора, має бути орієнтованим на рівноправність та взаємне збагачення партнерів через систему «педагог - студент - музика - учень». Зауважимо, що О. Рудницька (2010) приділяла значну увагу діалогічним формам (міжособистісний та внутрішній діалог) художнього спілкування в процесі розвитку педагогічної культури студентів. Цілком слушно науковець виділила «інтегральні особистісні 
якості майбутнього вчителя музичного мистецтва» (комунікативність, емпатію, креативність та рефлексію), що сприяють досягненню високого рівня оволодіння «мистецтвом душевного контакту 3 учнями». Автором наголошено на важливості співпереживання та співчуття, що сприяють художньому спілкуванню учнів із творами музичного мистецтва. На основі цих форм виявляється і формується спільність настроїв і думок вчителя та учнів, виникає згуртованість між ними (Рудницька, 2010).

Проблема підготовки майбутнього вчителя до співпраці знайшла відображення в працях Н. Мозгальової (2012), яка акцентує увагу на організації творчо-динамічної педагогічної взаємодії викладача й студента, спрямованої до співпраці в інструментально-виконавській діяльності. Автор підкреслює значущість принципу творчої взаємодії викладача й студента в досягненні виконавського успіху (Мозгальова, 2012, с. 15).

Деякі аспекти підготовки майбутніх учителів мистецьких дисциплін до співпраці досліджував В. Орлов (2003). А саме ті питання, які пов'язані 3 налагодженням: a) інтелектуального діалогу між викладачем і студентом як особливої форми їхнього спілкування, що збагачує самопізнання шляхом обміну думками в процесі професійного становлення фахівця; б) духовного спілкування як спільного опрацювання узагальнених уявлень, понять, установок, поглядів, ідеалів суб'єктів художньо-педагогічного спілкування, тобто досягнення спільними зусиллями духовної спільності (Орлов, 2003, с. 166).

На думку В. Орлова (2003), особливістю художньо-педагогічного розвитку майбутнього вчителя музики $є$ розвинене вміння так організовувати освітній процес, аби викликати в учнів бажання спілкуватися з мистецтвом, формувати в них потребу в пошуках сутності й смислів, роздумах над загальнолюдськими цінностями, потребу у високих естетичних почуттях і переживаннях (Орлов, 2003 , c. 56 ).

Т. Смирнова (2008) зверталася до вирішення проблем підготовки майбутніх учителів до співпраці. Дослідниця вважає, що співпраця є найбільш впливовою формою інтерактивної взаємодії співаків та диригента хору, що втілюється в їхньому творчому діалозі (обміні музичними ідеями та імпульсами), у спільній репетиційній і концертній діяльності. Т. Смирнова розуміє співпрацю як спосіб підвищення професійного особистісного розвитку його учасників, що сприяє розширенню їхніх індивідуальних можливостей та взаємозбагаченню (Смирнова, 2008, с. 179-180).

Отже, аналіз наукової літератури дозволяє визначити, що проблема підготовки майбутніх учителів до співпраці 3 учнями певною мірою 
Готовність майбутніх учителів музики до співпраці з учнями в освітньому процесі Нової української школи

досліджувалася провідними зарубіжними та українськими вченими в галузі музично-педагогічної освіти.

Формулювання цілей статті (постановка завдання). Проте наразі немає єдиного системного узагальнення всіх аспектів підготовки майбутніх учителів музики до співпраці з учнями. 3 огляду на це, виникає потреба визначити структуру та обгрунтувати зміст компонентів готовності майбутніх учителів музики до співпраці з учнями в освітньому процесі, що й становить мету статті.

Результати дослідження. Теоретичне опрацювання наукової літератури дало змогу виділити структуру підготовки майбутніх учителів музики до співпраці з учнями, що містить такі компоненти: особистісно-аксіологічний, когнітивний та праксеологічний.

Розглянемо зміст кожного компонента окресленої структури докладніше.

Зміст особистісно-аксіологічного компонента полягає у формуванні професійно важливих якостей майбутніх учителів музики (дружелюбності, оптимізму, толерантності, відповідальності, тактовності та справедливості) в процесі усвідомлення студентами значущості співпраці як загальнолюдської норми взаємовідносин, що спирається на систему загальнолюдських, професійно-педагогічних та художніх цінностей.

Спираючись на дослідження О. Рудницької, можна стверджувати, що підготовка майбутніх учителів музики передбачає «процес становлення особистості студентів як носіїв та творців цінностей» (Рудницька, 2010, с. 35). Особливо великого значення цей факт набуває в підготовці майбутніх учителів музики до співпраці з учнями.

Особистісні цінності майбутнього вчителя музики є одним із джерел його мотивації до професійної діяльності, вони формуються в процесі проходження соціальних цінностей через посередництво індивідуальної життєдіяльності й належать до психологічної структури його особистості.

Можна припустити, що поєднання естетичного та етичного потенціалів музичного мистецтва сприяє налагодженню музично-творчої співпраці, що буде набувати ознак не просто раціональної або чуттєвої гармонії, а трансформується в живі й теплі стосунки, які регулюють поведінку майбутнього вчителя у взаємодії з собою, учнями та музичним мистецтвом.

О. Рудницька наголошує на тому, що особистість у процесі художнього спілкування змінюється під впливом мистецтва і це спонукає ії до подальшого міжособистісного спілкування з іншими суб'єктами художньої діяльності, у якому обговорюються різні варіанти суджень щодо художніх цінностей, творчості митців. Дослідниця вважає, що такі дискусійні розмови ефективно 
позначаються на загальному розвитку комунікативності, що виявляється в здатності до розуміння себе й інших партнерів спілкування (Рудницька, 2010, c. 30). Музика є каналом невербального спілкування, що має функцію передачі духовних цінностей. Тому художні цінності є засобами, що здатні передавати, а через це й узгоджувати цінності вчителя й учнів, об'єднувати їхні такі різні світи через свою властивість бути універсальними накопичувачами досвіду людства, бути актуальними для кожного за всіх часів (Ткаченко, 2016).

Отже, стрижнем підготовки майбутніх учителів музики до співпраці 3 учнями вважаємо систему загальнолюдських, професійно-педагогічних та художніх цінностей.

Розглянемо сутність когнітивного компонента підготовки майбутніх учителів музики до співпраці з учнями, що містить систему інтегрованих знань про зміст і способи навчальної та музично-творчої співпраці з учнями.

Метою зазначеного компонента є усвідомлення майбутніми вчителями музики загальних теоретико-методичних положень співпраці та їх перенесення у сферу музичної педагогіки. У педагогічному словнику термін «знання» визначається як особлива форма духовного засвоєння результатів пізнання, процесу відображення дійсності, яка характеризується усвідомленням їхньої істинності й виражається в поняттях, судженнях, умовиводах, концепціях i теоріях. Навчальна функція знань полягає у забезпеченні таких їхніх якостей, як повнота, систематичність, усвідомленість, міцність і дієвість. Для забезпечення цих якостей знань у процесі виділення кола понять зі співпраці був використаний системний та інтегративний підходи, що дозволили створити систему інтегрованих знань зі співпраці, яка складається з аксіологічних, психологічних, педагогічних, соціологічних, музично-педагогічних, музично-теоретичних та музично-практичних груп понять згідно з дисциплінами фундаментального та професійно-практичного циклів підготовки майбутніх учителів музики.

Інтеграція знань на основі співпраці зумовлена об'єктивними передумовами об'єднання раніше незалежних понять, а саме наявністю істотних взаємозв'язків, які визначають та змінюють функціонування обраної інформації в бік позитивної взаємодії суб’єктів освітнього процесу.

Аналіз наукової музично-педагогічної літератури показав, що ефективність підготовки майбутніх учителів музики до співпраці з учнями залежить від усвідомлення ними сутності співпраці та перенесення його змісту в мистецький освітній простір.

Аналіз навчальних планів і програм підготовки майбутніх учителів музики показав, що такі поняття, як «музична співпраця», «мистецький діалог» й 
«співроздуми» можуть вивчатися студентами на таких дисциплінах, як «Вступ до спеціальності», «Основний музичний інструмент», «Диригування», «Постановка голосу», «Хоровий клас», «Оркестровий клас», «Хорознавство», «Методика навчання музики», «Практикум шкільного репертуару», «Практикум роботи з хором», «Художньо-педагогічний аналіз творів мистецтва».

На нашу думку, найважливішою інтеграційною інформацією, що має бути засвоєна майбутніми вчителями музики є знання про те, що співпраця - це загальний принцип побудови буття, який пронизує всі сфери життя людини, наповнюючи їх новими смислами, якостями. Так, цікавим $\epsilon$ інтегроване розуміння слів із префіксом спів-, що в поєднанні зі звичними словами (діяльність, творчість, управління, чуття тощо) народжує нові значення, ознаки, образи дії, що задають перспективу розгляду цих термінів, змінюють методологію їхнього «розгортання». Тому це явище $\epsilon$ джерелом професійного розвитку студентів, а саме вчить не консервативному, а прогресивному погляду на речі.

Значущою інтегрованою думкою також $є$ вираз, що сприймання навколишнього світу як гармонійної єдності - це свідчення гармонії та врівноваженості внутрішнього світу людини, i, навпаки, згода всередині внутрішнього діалогу особистості майбутнього вчителя музики призводить до гармонізації його стосунків ззовні.

Отже, систематизація та інтеграція знань майбутніх учителів музики 3 різних аспектів професійної діяльності на основі принципів, ознак, форм і видів співпраці забезпечує цілісне змістове наповнення досліджуваної підготовки.

Розглянемо третій - праксеологічний компонент підготовки майбутніх учителів музики до співпраці з учнями в освітньому процесі.

На думку Є. Проворової (2017), готовність до співпраці з учнями має вирізнятися продуктивністю, ефективністю, результативністю та успішністю як праксеологічними складниками музично-педагогічної діяльності вчителя музики. У підготовці здобувачів вищої освіти до співпраці з учнями важливим $\epsilon$ оволодіння групою комунікативно-організаціних умінь. Через те, що в основі педагогічної діяльності лежить спілкування, від того, як і яким чином майбутній учитель транслює інформацію, залежить якість формування його навчальних та міжособистісних відносин з учнями, а також надалі результативність процесів навчання та виховання.

Комунікативний аспект професійної діяльності майбутнього вчителя, на думку О. Дубасенюк, Т. Семенюк і О. Антонової (2003, с. 21), має виявлятися у встановленні доцільних, доброзичливих стосунків із вихованцями, що 
Готовність майбутніх учителів музики до співпраці з учнями в освітньому процесі Нової української школи

передбачає прояв педагогічного такту, душевної чутливості, делікатності, терпимості, милосердя у виховній роботі з учнями, а організаторський аспект сприяти індивідуальному розвитку особистості, іii природних задатків, формуванню високорозвиненого учнівського колективу.

У процесі підготовки майбутніх учителів музики до співпраці з учнями виділяють завдання, що передбачають упровадження ідей колективного творчого навчання, творчого самоуправління, а саме: а) інтеграцію різних поглядів та думок учнів, б) організацію мистецького діалогу, в) творення колективної музичної інтерпретації, г) ансамблювання та акомпанування в процесі виконання музичного твору.

Провідною в співпраці, на нашу думку, є ідея діалогічних роздумів, що сприяє розвитку розумових здібностей учнів. Учені вказують на необхідність створення діалогу вчителя з учнями в освітньому процесі. Через співроздуми вчителя з учнями в пошуку вирішення навчальних проблем, доброзичливе та уважне ставлення до висловлювань дітей, заохочення їхніх ідей, думок, навіть невдалих і невірних, стимулювання активності відбувається гуманістичне виховання школярів. Саме тому в підготовці майбутніх учителів музики до співпраці з учнями необхідним $є$ оволодіння комунікативно-організаційними вміннями організовувати міжособистісний та музично-творчий діалог з учнями.

Висновки. Отже, підготовка майбутніх учителів музики до співпраці 3 учнями в умовах нової української школи - це процес і результат виховання загальнолюдських та професійних цінностей студентів, професійно важливих якостей, засвоєння ними знань та оволодіння вміннями, що забезпечують ефективність міжособистісного та мистецького діалогу, реалізацію музичної співтворчості з учнями в освітньому процесі, і є невід’ємним складником професійної компетентності майбутніх учителів музики.

\section{СПИСОК ВИКОРИСТАНИХ ДЖЕРЕЛ:}

1. Беземчук, Л. В. (2017). Підготовка майбутнього вчителя музичного мистецтва до викладання основного змісту шкільної освіти. Мистецька освіта : історія, теорія, технології : зб. наук. пр. За заг. ред. Т. А. Смирнової. Харків : ХНПУ, с. 271-288.

2. Дубасенюк, О. А., Семенюк, Т. В. і Антонова, О. Є. (2003). Професійна підготовка майбутнього вчителя до педагогічної діяльності. Житомир : Житомир. держ. пед. ун-т.

3. Концепція Нової української школи. (2016). Взято 3 https://mon.gov.ua/storage/app/media/zagalna\%20serednya/nova-ukrainska-shkolacompressed.pdf

4. Рудницька, О. П. (2010). Мистецька освіта в Україні : теорія і практика. Заг. ред. О. В. Михайличенко, ред. Г. Ю. Ніколаї. Суми : СумДПУ ім. А. С. Макаренка.

5. Мозгальова, Н. Г. (2012). Теорія та методика інструментально-виконавської підготовки майбутніх учителів музики. (Автореф. дис. д-ра пед. наук). Київ: Нац. пед. ун-т ім. М. П. Драгоманова. 
Готовність майбутніх учителів музики до співпраці з учнями в освітньому процесі

Нової української школи

6. Орлов, В. Ф. (2003). Професійне становлення вчителів мистецьких дисциплін. Київ: Наукова думка.

7. Проворова, Є. М. (2017). Методична підготовка майбутнього вчителя музики на засадах праксеологічного підходу : теорія і практика. Суми: Вид-во СумДПУ імені А. С. Макаренка.

8. Смирнова, Т. А. (2008). Теорія та методика диригентсько-хорової освіти у вищих навчальних закладах: психолого-педагогічний аспект. Горлівка : ПП «Видавництво Ліхтар».

9. Ткаченко, Т. В. (2016). Формування вокально-сценічної культури студентів мистецьких факультетів педагогічних вузів. Харків: ХНПУ ім. Г.С. Сковороди.

\title{
FUTURE MUSIC TEACHERS' PREPAREDNESS FOR COOPERATION WITH THE STUDENTS IN THE EDUCATIONAL PROCESS OF THE NEW UKRAINIAN SCHOOL
}

\author{
Valentyna Zamorotska \\ Candidate of Pedagogical Sciences, Associate Professor \\ Music and Choreography Department \\ SHEI "Donbas State Pedagogical University" \\ Sloviansk, Donetsk region, Ukraine \\ zamorotska@i.ua
}

\section{Volodymyr Smyrenskyi}

Candidate of Pedagogical Sciences, Associate Professor, teacher-specialist of the cycle commission "Choral Conducting"

CE "Bakhmut Professional College of Culture and Arts named after I. Karabyts"

Bakhmut, Donetsk region, Ukraine

ORCID ID 0000-0002-0837-0167

smirensk22@gmail.com

\begin{abstract}
The article is devoted to the certain aspects of forming the future music teachers' professional competence, in particular the relevant issue of the teachers' readiness for cooperation with schoolchildren in the educational process. The problem of the future music teachers' training for cooperation was reflected in the studies of L. Bezemchuk, N. Mozgalova, V. Orlov, Ye. Provorova, T. Smyrnova and others. The authors explain the formation of the future music teachers' readiness to collaborate with students as a process and a result of educating students' universal and professional values, of professional qualities, mastering their knowledge and mastering skills that ensure the effectiveness of interpersonal and artistic dialogue, the implementation of musical co-creation with students in the educational process. The authors underline that the future music teacher's personal values are ones of the sources of his/her motivation for professional activity. The peculiarity of the artistic and pedagogical development of the future music teachers is the ability to organize the educational process in order to encourage the schoolchildren to communicate with art, to form their need for search of essence and meanings, reflection on universal values, the need for high aesthetic feelings and experiences.

In the structure of the concept the authors distinguish and characterize personality-axiological, cognitive and praxeological components. The content of the personality-axiological component is the formation of the future music teachers' professionally important qualities (friendship, optimism, tolerance, responsibility, tact and justice) through the understanding cooperation as a universal human
\end{abstract}

Професіоналізм педагога: теоретичні й методичні аспекти. - Вип. 16. - Слов’янськ, 2021. 
norm based on the system of universal, pedagogical and artistic values. The cognitive component contains a system of integrated knowledge about the content and ways of educational and musical and creative collaboration with schoolchildren. The praxeological component means mastering the group of communicative and organizational skills.

Key words: professional training; future music teachers; preparedness to cooperate; structure.

\section{REFERENCES}

1. Bezemchuk, L. V. (2017). Pidhotovka maibutnoho vchytelia muzychnoho mystetstva do vykladannia osnovnoho zmistu shkilnoi osvity [Preparing a future music teacher to teach the basic content of school education]. Mystetska osvita : istoriia, teoriia, tekhnolohii : zb. nauk. pr. Za zah. red. T. A. Smyrnovoi. Kharkiv, Ukraine: KhNPU, p. 271-288. [in Ukrainian].

2. Dubaseniuk, O. A., Semeniuk, T. V. \& Antonova, O. Ye. (2003). Profesiina pidhotovka maibutnoho vchytelia do pedahohichnoi diialnosti [Professional training of future teachers for pedagogical activities]. Zhytomyr, Ukraine : Zhytomyr. derzh. ped. un-t. [in Ukrainian].

3. Kontseptsiia Novoi ukrainskoi shkoly [The Concept of the New Ukrainian school]. (2016). Retrieved from https://mon.gov.ua/storage/app/media/zagalna\%20serednya/nova-ukrainskashkolacompressed.pdf [in Ukrainian].

4. Rudnytska, O. P. (2010). Mystetska osvita v Ukraini: teoriia i praktyka [Art education in Ukraine: theory and practice]. Eds. O. V. Mykhailychenko, H. Yu. Nikolai. Sumy, U: SumDPU im. A.S. Makarenka. [in Ukrainian].

5. Mozghalova, N. H. (2012). Teoriia ta metodyka instrumentalno-vykonavskoi pidhotovky maibutnikh uchyteliv muzyky [Theory and methods of instrumental and performance training of future music teachers]. (Thesis of Doct. Dissertation). Kyiv, Ukraine: Nats. ped. un-t im. M.P.Drahomanova. [in Ukrainian].

6. Orlov, V.F. (2003). Profesiine stanovlennia vchyteliv mystetskykh dystsyplin [Professional development of teachers of art courses]. Kyiv, Ukraine: Naukova dumka. [in Ukrainian].

7. Provorova, Ye. M. (2017). Metodychna pidhotovka maibutnoho vchytelia muzyky na zasadakh prakseolohichnoho pidkhodu: teoriia i praktyka [Methodical preparation of the future music teacher on the basis of praxeological approach: theory and practice]. Sumy, Ukraine: Vyd-vo SumDPU imeni A.S. Makarenka. [in Ukrainian].

8. Smyrnova, T. A. (2008). Teoriia ta metodyka dyryhentsko-khorovoi osvity u vyshchykh navchalnykh zakladakh: psykholoho-pedahohichnyi aspect [Theory and methods of conducting and choral education in higher educational institutions: psychological and pedagogical aspect]. Horlivka, Ukraine: PP "Vydavnytstvo Likhtar". [in Ukrainian].

9. Tkachenko, T. V. (2016). Formuvannia vokalno-stsenichnoi kultury studentiv mystetskykh fakultetiv pedahohichnykh vuziv [ormation of vocal and stage culture of students of art faculties of pedagogical universities]. Kharkiv: KhNPU im. H.S. Skovorody. [in Ukrainian].

\section{Матеріали надійшли до редакції 07.10.2021 p.}

